\title{
Sustainable urban mobility in Rio de Janeiro: A model to quantify greenhouse gas emissions and purpose of practical application
}

Camila de Mello Cardoso de Oliveira1', Mariana Gonçalves de Carvalho Wolff ${ }^{2}$

${ }^{1}$ Federal Center of Technological Education of Rio de Janeiro - CEFET/RJ, Campus Nova Iguaçu, Nova Iguaçu, RJ, Brazil.

${ }^{2}$ Federal Rural University of Rio de Janeiro - UFRRJ, Administration and Tourism Department, Multidisciplinary Institute, Nova Iguaçu, RJ, Brazil.

How to cite: Oliveira, C.M.C. and Wolff, M.G.C. (2020), "Sustainable urban mobility in Rio de Janeiro: A model to quantify greenhouse gas emissions and purpose of practical application", Brazilian Journal of Operations \& Production Management, Vol. 17, No. 03, e2020993. https://doi.org/10.14488/10.14488/B]OPM.2020.030

\begin{abstract}
Goal: This article aims to present a mathematical modelling study to quantify greenhouse gas emissions in the scope of urban mobility and propose actions for more sustainable cities.

Methodology: This presents an application focused on trips made by cars and motorcycles in some neighborhoods of the City of Rio de Janeiro during 2016 in order to quantify from mathematical equations the greenhouse gas emissions and their proportion to the total greenhouse gases emission of transport in the city, while presenting the capacity of the current bicycle infrastructure to absorb the same displacements with zero carbon trips.

Results: The study reached the result of 127 thousand tons of greenhouse gases emitted by cars and motorcycles, representing $1,64 \%$ of the total transport emissions and $2,73 \%$ of road transport in this city in 2016.

Limitations of the investigation: The research is limited to the neighborhoods under analysis and the daily travel rate per inhabitant by type of transport.

Practical implications: The study provides environmental impact assessment material able to support proposals for practical applications aimed at mitigating greenhouse gas emissions.

Originality / Value: Measurement of environmental impacts and applications in the transport of the city of Rio de Janeiro, which can be used for comparisons with other neighborhoods in the city and/or other cities.
\end{abstract}

Keywords: Cycleways; Bicycle; Greenhouse Gases Emission.

\section{INTRODUCTION}

The urban densification is a characteristic present in Brazilian cities. The impacts in large centers are generated by the increasing level of urbanization that occurred in Brazil, which intensified at the end of the 20th century (Saraiva et al., 2019). According to Dotto and Silva (2019), such impacts have as some consequences negative influence on environmental aspects and on the quality of life of the urbanized population, which, according to the last demographic census in 2010 made by IBGE, represents $84 \%$ of the population Brazilian.

It is observed that urban planning is the responsibility of public administration and its inefficiency becomes the major cause of the problems of disorderly occupation of land. As part

Financial support: None.

Conflict of interest: None.

Corresponding author: camilamelloco@gmail.com

Received: 03 Jun 2020

Accepted: 26 July 2020

Editor: Fernando Oliveira de Araujo and Chrystyane Abreu 
of urban planning, the National Confederation of Municipalities (Confederação Nacional de Municípios, 2016) establishes that city governments of cities of more than 20 thousand inhabitants must prepare municipal mobility plans. However, according to data from Instituto Brasileiro de Geografia e Estatística (2012), only 10\% of municipalities they have them and, as a consequence, the remaining $90 \%$ cities distance themselves from the National Urban Mobility Policy.

According to DENATRAN, in 2018 Brazil had a car for every 4 inhabitants and yet according to Instituto de Pesquisa Econômica Aplicada (2013) $18.6 \%$ of the inhabitants who live and work in Brazilian metropolitan regions spend more than one daily time commuting from home to work. Not only the negative impact on mobility, the use of cars is one of the contributors of greenhouse gas emissions and negative air quality (Rubim and Leitão, 2013; Pasha et al., 2016), since transport is responsible for approximately a quarter of the carbon emission by human action (Wang et al., 2018). Such factors contribute to the current environmental crisis in which the solution is sought using sustainable methods (De Lima et al., 2012).

Santos (2007) suggests that one of the measures to discourage vehicular gas emissions is to increase the effort in the development of mobility with the use of non-polluting transport sources and among this cycling mobility can be highlighted. The use of bicycles in Brazil grew with the oil crisis and declined in the 1980s and early 1990s (Affonso et al., 2003) and currently the Brazilian Traffic Code (Law No. 9.503, of September 23, 1997) includes it as a vehicle in which municipalities must plan and guarantee the safety of their circulation. The use of non-polluting transport prevents a greater emission of greenhouse gases, as shown by data from the research carried out by Laboratório de Mobilidade Sustentável (2018) in which it is estimated that the current Brazilians who already use the bicycle instead of cars stop emit 4.4 kilos of carbon dioxide per year.

The city of Rio de Janeiro is the second most populous city in Brazil and the capital of its state. In recent years, the city has been expanding its cycle infrastructure to enable new possibilities for travel and integration with other modes. This article aims to assess what is the possible reduction in greenhouse gas emissions in the scope of the city of Rio de Janeiro from the migration of users of individual motor vehicles to cycle transport, considering some neighborhoods in this city in 2016.

The study is structured in 5 sections. Section 1 introduces the theme of greenhouse gas emissions in transport and the impact of cycling mobility on reducing it. The second brings a review of the literature, detailing concepts of urban mobility and sustainable urban mobility and studies related to the theme of transport and its adaptations to Brazilian public policy. The methodology used and the case study in the city of Rio de Janeiro are presented below. Section 4 analyzes the results obtained in this study and, finally, the conclusion seeks to finalize the theme and propose public measures to reduce the emission of greenhouse gases in transport.

\section{LITERATURE REVIEW}

Several studies demonstrate Brazil's historic adequacy to sustainable urban mobility. For example, according to Pereira (2015), Brazil treated urban mobility as a sectorial and specialized way, in which the planning and regulation of collective transport, transit, urban logistics and road infrastructure was processed separately. So, the National Urban Mobility Policy becomes the instrument of development policy aiming at "the integration of different modes of transport and the improvement of accessibility and mobility of people and cargo in the territory of the municipality" (Law No. 12,587, of 3 January 2012).

Comparing the Brazilian capitals with a greater cycle length with the capitals of other countries, Brazil presents a similar mesh size. According to data from Associação Brasileira dos Fabricantes de Motocicletas, Ciclomotores, Motonetas, Bicicletas e Similares (2018), the Brazilian cities São Paulo, Rio de Janeiro and Brasília have respectively 498, 458 and 465 kilometers of cycleways, similar in measure to the city of Bogotá, with 402 kilometers and Copenhagen, 
with 350 kilometers. According to the same data, there is a contrast in size with the city of Berlin, which has 750 kilometers of cycleways.

According to Pereira (2015), urban road planning has been modified in several societies to promote more sustainable development in a way that considers the pedestrians and cyclists mobility. Pasha et al. (2016) note the need for analysis by policy makers and planners of the criteria that influence the choice of the active mode of transport to encourage its use. Luo et al. (2020) state that the planning of cycling routes should also take into account, in addition to the general planning criteria, the exposure of air pollution related to traffic that affects cyclists.

Current studies on bicycle transport focus on case studies on the deployment of shared bicycle systems. Sousa-Zomer et al. (2016) study bicycle sharing models as a potentially effective initiative in developed and underdeveloped countries to increase the supply of sustainable transport. Wang et al. (2020) also deal with bicycle sharing systems when reporting the benefits of reduced commuting time and carbon footprint on travel by public bicycles in 2016 in the city of Hohhot, the capital of Mongolia.

Brazil is the seventh largest emitter of greenhouse gases in the world (Observatório do Clima, 2018). According to data from the Greenhouse Gas Emission Estimation System (2018), the transport sector in this country participated with $11 \%$ of emissions in 2016 . Despite the $110 \%$ growth since 2004 , the participation of the activity economic growth has remained stable since 2012 , remaining in the range of $10 \%$ from this year.

In the literature presented there are articles that calculate the amount of greenhouse gases emitted in transport and suggests the migration of polluting transport of people to the bicycle in order to reduce such emissions. Among these, Yang et al. (2017) note that the city of Beijing, which is a developed city and has good traffic and rail services, emits carbon dioxide approximately 7 times more than Xi'an, a rapidly developing city. Neves and Brand (2019) analyze the potential reduction of short trips made by cars due to the migration of the use of bicycles or walks by 50 residents of Cardiff and find the substitution favorable on $41 \%$ of these. And the study by Sun et al. (2020) analyzed the potential reduction in greenhouse gas emissions by motor vehicles by replacing the journey made by such modals with shared bicycles available next to the stations on line 10 of the Beijing subway.

Based on the literature review, this study also uses travel and population data from the last census conducted (Instituto Brasileiro de Geografia e Estatística, 2010), Metropolitan Region of Rio de Janeiro Transport Master Plan (2014) and a general report on transport conducted by the Associação Nacional de Transportes Públicos (2018).

\section{METHODS}

\section{Research objective and focus}

The article proposes to quantify the greenhouse gas emissions from automobiles and motorcycles in the city of Rio de Janeiro in 2016 considering ten nearby neighborhoods that have a satisfactory bicycle infrastructure and intense flow of people connecting to the central area of the city and compares emissions of these gases due to transportation in the city. For that, the trips made that could be migrated for the use of bicycles are quantified, the greenhouse gas emissions generated by each mode are estimated and the emissions obtained are compared with the total of the city.

For data collection, the following were taken into account, respectively:

a) estimate of inhabitants of the neighborhoods covered in 2016;

b) analysis of the bicycle infrastructure of the neighborhoods covered by the research;

c) estimate of trips made by bicycle, automobiles and motorcycles in the neighborhoods covered by the survey in 2016;

d) estimate of greenhouse gas emissions by automobiles and motorcycles in the neighborhoods covered by the survey in 2016 . 


\section{Mathematical methodology}

For the calculation of the models previously analyzed, equations were prepared to list the estimates of inhabitants, the trips made and the emission of greenhouse gases in 2016.

The estimate of the number of inhabitants of the neighborhoods covered by the research was based on the number of inhabitants of each one, reported by the last demographic census carried out in the country (Instituto Brasileiro de Geografia e Estatística, 2010), and the estimate of expansion of inhabitants of the city between the years 2010 and 2016 (Instituto Brasileiro de Geografia e Estatística, 2016). The equation for calculating the estimated number of inhabitants of the neighborhoods covered by the survey in 2016 is:

$$
\mathrm{x}=\sum_{\mathrm{i}=1}^{10} \mathrm{Gi}^{*}\left(282244 * 10^{(-7)}\right)
$$

In Equation 1, x represents the sum of the estimated number of inhabitants in the 10 analyzed neighborhoods in 2016 and G represents the number of inhabitants per neighborhood according to the 2010 demographic census.

The following equations were developed based on the complementary composition and the calculation taken to quantify the emission of greenhouse gases in certain locations, as done by Sun, Wang and Li (2020).

The equation for calculating daily trips by cars, motorcycles and bicycles according to the number of inhabitants of the region is also based on the index already suggested for calculation carried out by the most recent Metropolitan Region of Rio de Janeiro Transport Master Plan (2014) and its data collected on the number of trips taken. Thus, the equation elaborated is:

$$
\mathrm{I}=\left(\frac{\mathrm{A}}{\mathrm{n}}\right)
$$

In Equation 2, I is the daily travel rate per inhabitant by type of transport. A is the number of trips analyzed by the collection of the Metropolitan Region of Rio de Janeiro Transport Master Plan (2014). Finally, $\mathrm{n}$ is the number of inhabitants present in the macro-zone of the Metropolitan Region of Rio de Janeiro in 2012.

The Equation 3, which comprises the estimate of trips made per day according to the number of inhabitants of the region, is:

$\mathrm{V}=\mathrm{Ix}$

In Equation 3, $\mathrm{V}$ is the estimate of daily trips made by the modes analyzed in the neighborhoods covered by the survey. $I$ is the rate of travel per day, per inhabitant and per type of transport, calculated in Equation 2. Finally, $x$ is the estimated number of numbers of inhabitants in the region in 2016, calculated in Equation 1.

The Equation 4 takes into account the data presented of daily emission of greenhouse gases per inhabitant by municipality population size (in this case, for municipalities above 1 million inhabitants) and mode of transport carried out by the Associação Nacional de Transportes Públicos (2018). The elaborated equation is:

$$
\mathrm{C}=\sum_{\mathrm{i}=1}^{2}\left(\mathrm{E}_{\mathrm{i}} * \mathrm{x}_{\mathrm{i}}\right) * 366
$$


In Equation 4, $\mathrm{C}$ is the total measured in tons of annual greenhouse gas emissions by cars and motorcycles in 2016 in the neighborhoods covered by the survey. The variable $\mathrm{E}$ is the quantity in tons of daily greenhouse gas emissions per inhabitant, adapted from the study by the National Public Transport Association (Associação Nacional de Transportes Públicos (2018), and $x$ is the estimated number of inhabitants in the region in 2016, calculated in the Equation 1. For the case study, the number of daily emissions was multiplied by 366 to calculate the annual greenhouse gas emissions, considering the calculation for a leap year.

\section{DISCUSSION ANALYSIS, RESULTS AND PROPOSALS}

\section{Bicycle infrastructure and modal integration viability}

For the research, the trips made in the neighborhoods Copacabana, Centro, Botafogo, Flamengo, Glória, Leme, Urca, Laranjeiras, Catete, Santa Teresa and Lapa were considered as shown in Figure 1. The neighborhoods are part of the city of Rio de Janeiro, in the state of Rio de Janeiro, with the neighborhoods Centro, Santa Teresa and Lapa belonging to the central area of the city and the rest belonging to the southern area. According to data from Ciclorio (2019), commuting by bicycle between neighborhoods throughout 2016 lasts less than 30 minutes. The average travel time by individual transport in cities with more than one million inhabitants is 30 minutes per trip (Associação Nacional de Transportes Públicos, 2018).

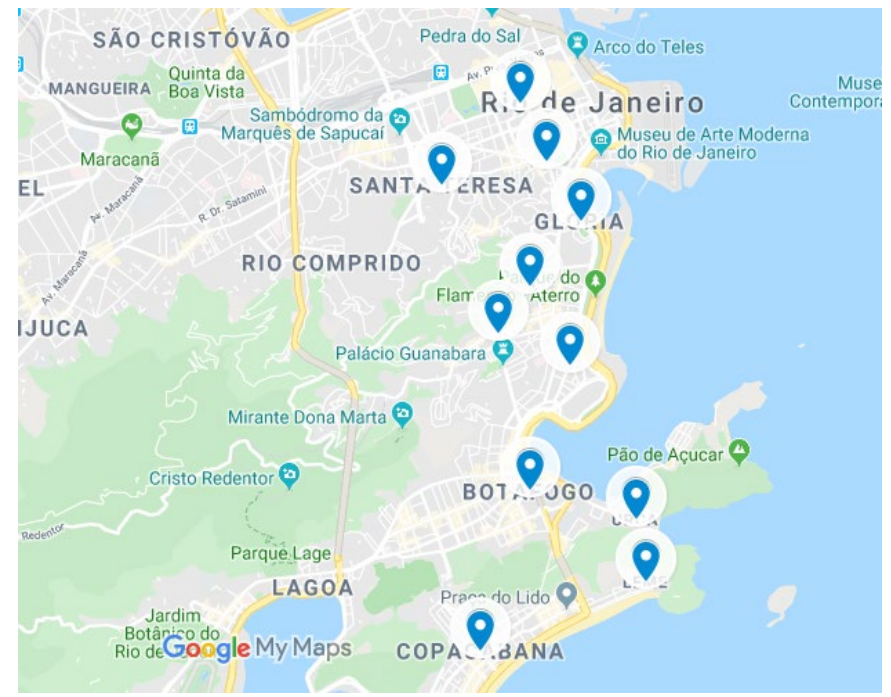

Figure 1. Map of neighborhoods covered by the survey Source: Designed from Google Maps (2019).

The city of Rio de Janeiro has the size of a metropolis (Lobo et al., 2018) in which cities with more than one million inhabitants are called. According to an IBGE estimate (2016), the city expanded the number of inhabitants by 2.82\% between 2010 and 2016 totaling $6,498,837$ inhabitants living in the municipality. Following the same estimate and Equation 1 , the neighborhoods covered by the survey have, in 2016, a total of 475,580 inhabitants, corresponding to $7.3 \%$ of the city's inhabitants.

All neighborhoods covered by the survey have ample mobility of means of public transport, with stations and subway lines such as subway transport and several lines and bus stops for road transport. The bicycle infrastructure in these neighborhoods is satisfactory and most of its roads have good conditions in signage and pavement, sufficient for the routine flow of the population to the surroundings (Maia, 2017). The neighborhoods have cycleways, bike lanes and sidewalks and shared roads as cycle paths in most of the busiest avenues and streets, and where there is an absence, usually on residential streets, there is the possibility of moving on foot transporting the bicycle along the route. 
The bicycle-sharing system has stations close to other modes, which facilitates integration with other types of public transport in the city. Along the neighborhoods, its subway stations and bus stops there are also bicycle stands for the use of the population, offered by the city hall. Such implantation allows the safe storage of bicycles, providing its users with the possibility of integration in areas where the use is prohibited.

Among the several cycleways located in the highlighted neighborhoods, the Mané Garrincha and Avenida Rio Branco cycleways are highlights. The Mané Garrincha cycleway has two lanes in two directions and, according to Maia (2017), it has a structure to accommodate the routine trip of the inhabitants to the surroundings. The average travel time is 20 minutes. The cycleway is 14 kilometers long, connecting the neighborhoods of Copacabana and downtown Rio de Janeiro in its borders with other neighborhoods, crossing the neighborhoods Botafogo, Flamengo and Glória. The neighborhoods Leme, Urca, Laranjeiras, Catete, Santa Tereza and Lapa are adjacent to the stretch, distant up to 2 kilometers from their limit zone.

The Avenida Rio Branco cycleway is 750 meters long and can take an average of 6 minutes to complete. Its route participates in the corporate center of the city, where a large number of offices and commercial services are located, which are work destinations for the inhabitants of the city and others nearby. It is also located close to the VLT tracks, enabling integration with the modal at 2 stations next to the cycleway.

\section{Analysis of greenhouse gas emissions}

The study analyzes the cases in which the use of vehicles emitting greenhouse gases can be substituted in relation to the modality. For the analysis, the replacement of individual motor vehicles was defined, in which the Metropolitan Region of Rio de Janeiro Transport Master Plan (2014) classifies them analytically as: auto driver, auto passenger, taxi, motorcycle and moto taxi. As the trips of auto driver, auto passenger and taxi configure the same vehicle and emit the same amount of pollutants, for the calculation of greenhouse gas emissions they are consolidated and are called car. Likewise, the situation with a motorcycle and a motorcycle taxi is analyzed together as a motorcycle.

Equation 2 allows the calculation of the index of travel per day and per inhabitant from the number of trips provided by the study of the Metropolitan Region of Rio de Janeiro Transport Master Plan (2014) and in Equation 3 the index is applied to estimate of inhabitants in the neighborhoods covered by the survey. Tables 1 and 2 reflect these values.

Table 1. Travel index per day by individual motorized transport and bicycle

\begin{tabular}{ccc}
\hline Means of transport & $\begin{array}{c}\text { Analyzed Trips - A } \\
\text { (thousand) }\end{array}$ & Index - I (trips/day/inhabitants) \\
\hline Auto driver & 2.540 & 0,211 \\
\hline Auto passenger & 1.225 & 0,102 \\
\hline Taxi & 256 & 0,021 \\
\hline Total of Car & 4.021 & 0,334 \\
\hline Motorcycle & 170 & 0,014 \\
\hline Motorcycle Taxi & 39 & 0,003 \\
\hline Total of Motorcycle & 209 & 0,017 \\
\hline Car + Motorcycle & 4.230 & 0,352 \\
\hline Bicycle & 546 & 0,045 \\
\hline
\end{tabular}

Source: The authors themselves 
Table 2. Total trips per day by modal analyzed in the neighborhoods

\begin{tabular}{ccc}
\hline Means of transport & Index - I & Total of trips/day \\
\hline Auto driver & 0,211 & 100.472 \\
\hline Auto passenger & 0,102 & 48.456 \\
\hline Taxi & 0,021 & 10.126 \\
\hline Total of Car & 0,334 & 159.054 \\
\hline Motorcycle & 0,014 & 6.724 \\
\hline Motorcycle Taxi & 0,003 & 1.542 \\
\hline Total of Motorcycle & 0,017 & 8.267 \\
\hline Car + Motorcycle & 0,352 & 167.321 \\
\hline Bicycle & 0,045 & 21.597 \\
\hline
\end{tabular}

Source: The authors themselves

According to the report of the National Public Transport Association (2018), in 2016 cars corresponded to $67 \%$ of the greenhouse gas emissions from the modes of road transport of people, while motorcycles were responsible for $4 \%$. In the same report, it is estimated that there is an emission of 700 grams per inhabitant of greenhouse gases per day when traveling by car in cities of more than 1 million people, and, if the trip is made by motorcycle, their emission is 28 grams per inhabitant per day. For the study, such emissions values already converted into tons are used for the application of Equation 4 as the variable $\mathrm{E}_{\mathrm{i}}$.

The application of Equation 4 demonstrates that the annual greenhouse gas emission of cars in the neighborhoods covered by the survey is approximately 122 thousand tons. In the same period, motorcycles emitted less than 5 thousand tons. Together, it is estimated an emission of approximately 127 thousand tons of greenhouse gases in the year.

The survey analyzed the number of bicycle, car and motorcycle trips that took place in the neighborhoods covered by the survey per day during 2016 based on travel indices per inhabitant per day for each mode. The total volume is 189 thousand and percentage of such trips between the three means and the number of trips made is shown in Figure 2. The trips made by car are greater than $80 \%$ for the means of transport that emit the most greenhouse gases among those analyzed.

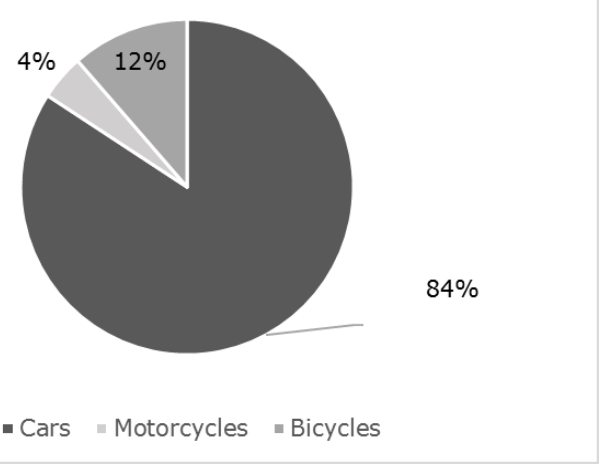

Figure 2. Number of daily trips made by car, bicycle and motorcycle in the neighborhoods (2016)

Source: The authors themselves

According to the most recent monitoring data on greenhouse gas emissions of the city of Rio de Janeiro (Climate Change Monitoring System, 2019), transport corresponds to 36\% of total emissions (equivalent to 7.7 million tons) in 2016. Thus, the 127 thousand tons emitted by cars and motorcycles in the neighborhoods covered by the survey correspond to $1.6 \%$ of emissions from all transport in the city of Rio de Janeiro. 
Analyzing by subsectors and according to the same data, the modal road, which includes the transportation of cargo and passengers, was responsible for emission of 4.6 million tons of greenhouse gases this year. In this volume, the emission in the neighborhoods covered by cars and motorcycles contribute $2.7 \%$ in relation to total road transport in the city.

\section{Propositions for action by policy makers}

As policy suggestions for improving environmental quality reducing greenhouse gas emissions, actions are proposed to expand cycle capacity and integrate modes, publicity campaigns for cycleways, reduction of road capacity for locomotion of individual transport and joint work with policy makers from other areas, shown in Table 3.

Table 3. Suggestions for political actions for travel migration in the neighborhoods covered by the survey

\begin{tabular}{cc}
\hline Policy suggestions & Suggested policy measures \\
\hline Increased cycling capacity & $\begin{array}{c}\bullet \text { Implementation of bike racks at new points } \\
\text { Increased supply of shared bicycle system stations } \\
\bullet \text { Creation of new cycleways }\end{array}$ \\
\hline $\begin{array}{c}\text { Expansion of integration with other } \\
\text { modes }\end{array}$ & $\begin{array}{c}\text { Increase in the supply of bicycles at shared bycicle systems } \\
\text { stations close to metro stations and bus stops } \\
\text { Disclosure of cycleways } \\
\text { Reduction of the individual motorized } \\
\text { trips capacity }\end{array}$ \\
\hline Integration with other policy areas & $\bullet$ Disclosure of advertisements on roadways \\
\hline
\end{tabular}

Source: The authors themselves

\section{CONCLUSION AND SUGGESTION FOR FUTURE STUDIES}

The study aimed to quantify greenhouse gas emissions of individual motor vehicles in the city of Rio de Janeiro in 2016, considering some neighborhoods in this city, and compare with the emissions of these gases due to transportation in the city. In this way, it analyzed the possibility of travel cars and motorcycles are migrated to bicycle trips, resulting in no greenhouse gas emissions. In addition, the research reinforces the possibility of studies on sustainable themes to quantitatively measure the impacts caused by greenhouse gas emissions in Brazilian cities.

According to the survey, the cycleways present in the neighborhoods of Rio de Janeiro South Zone and Central Zone, these being Copacabana, Centro, Botafogo, Flamengo, Glória, Leme, Urca, Laranjeiras, Catete, Santa Teresa and Lapa, in an interior position, such as the Avenida Rio Branco cycleway or in interconnection between them, such as the Mané Garrincha cycleway, is sufficient to support travel migration made by cars and motorcycles. The cycleways present good conditions of infrastructure, branching and signaling in which it allows accessibility and comfort to its users, in addition to interconnecting with streets and avenues residential neighborhoods, which makes it possible to use them for routine trips, such as home-work or home-school. Its implementation represents an adaptation of the city of Rio de Janeiro to sustainable urban mobility and the National Urban Mobility Policy.

Moreover, in these neighborhoods it is possible to transport a bicycle at specific times and subway wagons to integrate or use the cycle infrastructure with the subway transport, in which there is in the region several boarding and landing lanes and there is a future possibility of integration with public road transport by city buses. In this way, the cyclist guarantees more possibilities to move through the neighborhoods and to an external region without the need to do a trip by individual motor vehicle. Therefore, the bicycle infrastructure of the neighborhoods covered in the research is sufficient to carry out within them, in addition to being possible to transport a bicycle on residential roads and in the subway. 
The emissions of greenhouse gases by cars and motorcycles in the neighborhoods covered by the survey in 2016 represented $1.6 \%$ of total emissions from all modes of transport in the city of Rio de Janeiro in the same year and $2.7 \%$ of total road modals greenhouse gas emissions in the city, considering cargo and passenger transportation. According to the analysis, such emission could be reduced or even avoided, since the bicycle infrastructure allows for the same trips with the use of bicycles, a non-polluting mean of transport. The study also shows a much higher impact on the emission of greenhouse gases caused by automobiles when compared to that of motorcycles, considering the same distance covered and the greatest number of trips is made by them. Automobiles are responsible for $96 \%$ of the total greenhouse gases emitted while motorcycles are responsible for $4 \%$.

Although the study corresponds to greenhouse gas emissions caused in 2016, data from Departamento Nacional de Trânsito (2020) suggest the possibility of an increase in greenhouse gas emissions by cars and motorcycles in the city. Between 2016 and 2019 there was an increase in the fleet of $5 \%$ of cars and $12 \%$ of motorcycles, which consequently causes a greater number of trips and an increase in emissions.

The analysis provides the assessment of environmental impacts that can be taken into account when decision-making on sustainable urban mobility policies. As a suggestion for the reduction of such emissions, the city government can create incentive policies for the migration on the use of automobiles and motorcycles for the use of bicycles, in addition to expanding the existing bicycle infrastructure in order to promote greater cycle accessibility.

Other analyzes that can be done to complement the study are related to the comparison of atmospheric emissions between the areas of the city of Rio de Janeiro, identifying the relationship between transport emissions and the existence of the bicycle infrastructure. In addition, it is important to assess the financial impact for the collection of taxes and fees by the government and society as a result of the travel migration.

\section{REFERENCES}

Affonso, N., Badini, C. and Gouvea, F. (2003), Mobilidade e Cidadania, ANTP, São Paulo.

Associação Brasileira dos Fabricantes de Motocicletas, Ciclomotores, Motonetas, Bicicletas e Similares ABRACICLO (2018), Segurança MobAtiva, ABRACICLO, São Paulo. available at: https://www2.camara.leg.br/atividade-legislativa/comissoes/comissoes-permanentes/cvt/audienciaspublicas/audiencias-publicas-2018/arquivos-de-eventos/ap-26-06.18/abraciclo-parte-2 (accessed 03 June 2020).

Associação Nacional de Transportes Públicos - ANTP (2018), Sistema de informações da mobilidade urbana da Associação Nacional de Transportes Públicos - ANTP: Relatório geral 2016, ANTP, São Paulo. available at: http://files.antp.org.br/simob/simob-2016-v6.pdf (accessed 03 June 2020).

Ciclorio (2019), Mapa Cicloviário do Rio de Janeiro, CICLORIO, Rio de Janeiro.

Climate Change Monitoring System - SISCLIMA (2019), Monitoramento das Emissões de Gases de Efeito Estufa da Cidade do Rio de Janeiro 2012 a 2017: Apresentação dos Resultados, SISCLIMA, Rio de Janeiro.

Confederação Nacional de Municípios - CNM (2016), Mobilidade Urbana Municipal: A Gestão do Trânsito e o Plano de Mobilidade - Coletânea Gestão Pública Municipal: Gestão 2017 - 2020, CNM, Brasília. available at: https://www.cnm.org.br/cms/biblioteca/Mobilidade_Urbana-

A_gestao_do_transito_e_o_Plano_de_Mobilidade.pdf (accessed 03 June 2020).

De Lima, R., Carvalho, D., Vaccaro, G. et al. (2012), "Sustainability: An introduction view from ICIEOM", Brazilian Journal of Operations \& Production Management, Vol. 9, No. 2, pp. 9-14. available at: https://bjopm.emnuvens.com.br/bjopm/article/view/V9N2A1 (accessed 03 June 2020).

Departamento Nacional de Trânsito - DENATRAN (2020), Frota de Veículos - 2019, DENATRAN, Brasília. available at: https://infraestrutura.gov.br/component/content/article/115-portal-denatran/8559-frotade-veiculos-2019.html (accessed 03 June 2020).

Dotto, B. and Silva, A. (2019), "A representatividade da mobilidade urbana em certificações de sustentabilidade", Cidades, Comunidades e Territórios, No. 38, pp. 152-64. https://dx.doi.org/10.15847/citiescommunitiesterritories.jun2019.038.art05 
Google Maps (2019), available at: www.google.com.br/maps (accessed 03 December 2019).

Greenhouse Gas Emission Estimation System - SEEG (2018), Emissões do Setor de Mudança de Uso da Terra: Período 1990 - 2016, ISA, São Paulo. available at: http://www.observatoriodoclima.eco.br/wpcontent/uploads/2018/05/Relatórios-SEEG-2018-MUT-Final-v1.pdf (accessed 03 June 2020).

Instituto Brasileiro de Geografia e Estatística - IBGE (2010), Censo Demográfico 2020, IBGE, Brasília. available at: https://censo2010.ibge.gov.br (accessed 03 June 2020).

Instituto Brasileiro de Geografia e Estatística - IBGE (2016), IBGE Divulga as Estimativas da População dos Municípios em 2016, IBGE, Rio de Janeiro. available at: https://agenciadenoticias.ibge.gov.br/agenciasala-de-imprensa/2013-agencia-de-noticias/releases/9497-ibge-divulga-as-estimativas-populacionaisdos-municipios-em-2016 (accessed 03 June 2020).

Instituto Brasileiro de Geografia e Estatística - IBGE (2012), Município: Perfil dos Municípios Brasileiros 2012, IBGE, Brasília. available at: http:// www.ibge.gov.br/home/estatistica/economia/perfilmunic/2012/ (accessed 03 June 2020).

Instituto de Pesquisa Econômica Aplicada - IPEA (2013), Tempo de Deslocamento Casa-Trabalho no Brasil (1992 - 2009): Diferença entre Regiões Metropolitanas, Níveis de Renda e Sexo, IPEA, Brasília. available at: http://www.ipea.gov.br/portal/images/stories/PDFs/TDs/td_1813.pdf (accessed 03 June 2020).

Laboratório de Mobilidade Sustentável - LABMOB (2018), Economia da bicicleta no Brasil, LABMOB, Rio de Janeiro. available at: http://www.aliancabike.org.br/download-estudo-economiabicicleta/00c00/ECONOMIA_DA_BICICLETA_jul_18.pdf (accessed 03 June 2020).

Lobo, C., Cardoso, L. and Almeida, I. (2018), "Mobilidade pendular e integração regional: uma metodologia de análise para as regiões metropolitanas de Belo Horizonte, Rio de Janeiro e São Paulo", Cadernos Metrópole, Vol. 20, No. 41, pp. 171-89. available at: http://www.scielo.br/scielo.php?script=sci_arttext\&pid=S223699962018000100171\&lng=en\&nrm=iso (accessed 03 June 2020).

Luo, J., Boriboonsomsin, K. and Barth, M. (2020), "Consideration of exposure to traffic-related air pollution in bicycle route planning", Journal of Transport \& Health, Vol. 16. http://dx.doi.org/10.1016/j.jth.2019.100792.

Maia, A. (2017), "Avaliação da malha cicloviária do bairro de Botafogo/RJ”, Projectus, Vol. 2, No. 2, pp. 40-58. available at: http://apl.unisuam.edu.br/revistas/index.php/projectus/article/view/1549 (accessed 03 June 2020).

Metropolitan Region of Rio de Janeiro Transport Master Plan - SETRANS (2014), Plano Diretor de Transporte da Região Metropolitana do Rio de Janeiro, SETRANS, Rio de Janeiro. available at: http://www.rio.rj.gov.br/dlstatic/10112/5333332/4139325/25PDTUGovEstado092014.pdf (accessed 03 June 2020).

Neves, A. and Brand, C. (2019), "Assessing the potential for carbon emissions savings from replacing short car trips with walking and cycling using a mixed GPS-travel diary approach", Transportation Research Part A, Policy and Practice, Vol. 123, pp. 130-46. http://dx.doi.org/10.1016/j.tra.2018.08.022.

Observatório do Clima (2018), Estimativas de Emissões de Gases de Efeito Estufa no Brasil 1970 - 2017, Instituto Socioambiental, São Paulo. available at: http://www.observatoriodoclima.eco.br/wpcontent/uploads/2018/11/PPT-SEEG-6-LANCAMENTO-GERAL-2018.11.21-FINAL-DIST-compressed.pdf (accessed 03 June 2020).

Pasha, M., Rifaat, S., Tay, R. et al. (2016), "Urban design and planning influences on the share of trips taken by cycling", Journal of Urban Design, Vol. 21, No. 4, pp. 471-80. http://dx.doi.org/10.1080/13574809.2016.1184567.

Pereira, G. (2015), Índice de Desempenho da Infraestrutura Viária para a Mobilidade Urbana Sustentável, Tese de Doutorado, Programa de Pós-graduação em Engenharia de Produção, Universidade Federal Fluminense, Niterói.

Rubim, B. and Leitão, S. (2013), "O Plano de Mobilidade Urbana e o futuro das cidades", Estudos Avançados, Vol. 27, No. 79, pp. 55-66. http://dx.doi.org/10.1590/S0103-40142013000300005.

Santos, U. (2007), "Poluição, aquecimento global e repercussões na saúde", Revista da Associação Médica Brasileira, Vol. 53, No. 3, pp. 193-4. available at: http://www.scielo.br/scielo.php?script=sci_arttext\&pid=S010442302007000300004\&lng=en\&nrm=iso (accessed 03 June 2020).

Saraiva, P., Ribeiro, L. A., Neckel A. et al. (2019), "Avaliação da influência do entorno no uso das estações de bicicletas compartilhadas" Urbe. Revista Brasileira de Gestão Urbana, Vol. 11, pp. e20180105. http://dx.doi.org/10.1590/2175-3369.011.001.AO13. 
Sousa-Zomer, T., Cantú, V. and Cauchick Miguel, P. (2016), "Product-service systems as sustainable alternatives to mobility: A comparative analisys of two bike-sharing systems", Brazilian Journal of Operations \& Production Management, Vol. 13, No. 3, pp. 264-75. available at: https://doi.org/https://doi.org/10.14488/BJOPM.2016.v13.n3.a4 (accessed 03 June 2020).

Sun, S., Wang, B. and Li, A.R. (2020), "Shared bicycle study to help reduce carbon emissions in Beijing", Energy Reports, Vol. 6, Suppl. 1, pp. 837-49. http://dx.doi.org/10.1016/j.egyr.2019.11.017.

Wang, Z., Yefei, S., Yimeng, Z., et al. (2018), "Substitution effect or complementation effect for bicycle travel choice preference and other transportation availability: Evidence from US large-scale shared bicycle travel behaviour data", Journal of Cleaner Production, Vol. 194, pp. 406-15. http://dx.doi.org/10.1016/j.jclepro.2018.04.233.

Wang, Z., Xue, M., Zhao, Y. et al. (2020), "Trade-off between environmental benefits and time costs for public bicycles: An empirical analysis using streaming data in China", The Science of the Total Environment, Vol. 715. http://dx.doi.org/10.1016/j.scitotenv.2020.136847.

Yang, L., Wang, Y., Han, S. et al. (2017), "Urban transport carbon dioxide (CO2) emissions by commuters in rapidly developing Cities: The comparative study of Beijing and Xi'an in China", Transportation Research Part D, Transport and Environment, Vol. 68, pp. 65-83. http://dx.doi.org/10.1016/j.trd.2017.04.026.

Authors contribution: All the authors contributed equally to this paper. 